\title{
Usporedba momenta loma kutnog spoja izvedenoga upotrebom različitih ljepila
}

\section{The Fracture Moment of Corner Joint Bonded by Different Glues}

\author{
Preliminary paper • Prethodno priopćenje \\ Received-prispjelo: 2. 10. 2012. \\ Accepted-prihvaćeno: 6. 11. 2013. \\ UDK: $630 * 824.31 ; 674.028 .9$ \\ doi:10.5552/drind.2013.1248
}

\begin{abstract}
SAŽETAK • Cilj istraživanja bio je odabrati najpogodniju vrstu adheziva za novorazvijeni kutni spoj s drvenim prstenom. Primjena tog spoja najčešća je u proizvodnji prozorskih okvira. Kutni spoj s drvenim prstenom rezultat je slovenskog znanja i zaštićen je međunarodnim patentom. Rezultati sile loma u kutnih spojeva napravljenih uz pomoć različitih ljepila ispitivani su standardnom metodom na kidalici. Najbolji rezultati postignuti su upotrebom polivinilacetatnog ljepila grupe D3. Prednost primjene spoja s drvenim prstenom jest način proizvodnje koji omogućuje izradu okvira od prethodno površinski obrađenih elemenata koji se neposredno prije spajanja pile na željenu duljinu. Sastavljanjem dijelova proces izrade prozorskog krila završava. Zbog toga je izuzetno važno odabrati odgovarajuće ljepilo koje može potpuno ispuniti mjesto spoja i prekriti cijeli nezaštićen čelni dio elemenata u sastavu. Za tu su svrhu u eksperimentu upotrijebljena poliuretanska ljepila koja tijekom otvrdnjavanja djelomično ekspandiraju.
\end{abstract}

Ključne riječi: prozor, konstrukcije, spoj, drvo, ljepilo

\begin{abstract}
The main goal of this research is to determine the most appropriate adhesive to fix angular joints with wooden ring for manufacturing window frames. The joint with wooden ring is the result of Slovenian experience and is protected by international patent. The destructive strength of angular joints adhered with different glues was tested by the tensile-testing machine. Polyvinyl acetate glue of the D3 group was found to be the most appropriate from the point of view of strength. The biggest advantage of using a joint with wooden ring lies in the possibility of manufacturing wooden frames from finished elements. In this way, the process of manufacturing a window ends after assembling its parts. It is, therefore, very important to choose the right glue that can completely fill the junction and cover the whole unprotected front part of the joint. For this purpose, polyurethane glues were used in the experiment, as they slightly expand during the hardening phase.
\end{abstract}

Key words: window, construction, joint, wood, glue

\section{UVOD}

\section{INTRODUCTION}

Čvrstoća spojeva lijepljenih PVAc ljepilom ovisi o kvaliteti mehaničke obrade drvnih površina prije lijepljenja (Singh i sur., 2002), koje moraju biti ravne i određene hrapavosti, kao i o vremenu proteklome od obrade do nanošenja ljepila (Nussbaum i Sterley, 2002). Najkvalitetniji spoj može se postići lijepljenjem neposredno nakon obrade površine. Preporučljivi sadržaj vode u drvu jest 5 - $12 \%$, a za posebno pripremljena ljepila moguća su i manja odstupanja (Resnik,

\footnotetext{
${ }^{1}$ Autorica je izvanredna profesorica Akademije dizajna, Ljubljana, Slovenija. ${ }^{2}$ Autori su tehnički suradnik, profesor i izvanredni profesor Odjela za znanost o drvu i tehnologiju, Biotehnički fakultet, Sveučilište u Ljubljani, Ljubljana, Slovenija.

${ }^{1}$ Author is ssociated professor at the Academy of Design, Ljubljana, Slovenia. ${ }^{2}$ Authors are technical assistant, professor and associated professor at the University of Ljubljana, Biotechnical Faculty, Department of Wood Science and Technology, Ljubljana, Slovenia.
} 
1997). Istraživanja su pokazala da povećanje sadržaja vode u drvu od 12 na $15 \%$ oslabi čvrstoću lijepljenja za $15 \%$, dok je pri smanjenju sadržaja vode u drvu sa 12 na $8 \%$ ona veća za $6 \%$ (Tankut, 2007). Pri hladnom lijepljenju potrebno vrijeme prešanja spoja nakon priljubljivanja iznosi 10 - 20 minuta (Marra, 1992), dok je pri temperaturi $80{ }^{\circ} \mathrm{C}$ ono smanjeno na samo dvije minute. Potreban tlak je 2-15 MPa, što ovisi o vrsti drva i obilježjima sljubnica.

Logično je da površina sljuba određuje čvrstoću spoja. Dziegelewski i Zenkteler (1975) dokazuju tu tvrdnju uspoređujući čvrstoće ispitanih spojeva jednostrukim i dvostrukim utorom i perom te zaobljenim čepom, pri čemu je najveću čvrstoću imao spoj s dvostrukim utorom i perom, koji je ujedno imao i najveću površinu sljuba. Mnogi su autori istraživali čvrstoću kutnih spojeva s različitih stajališta. Hill i Eckelman (1973) odredili su utjecaj dimenzija čepa na krutost spojeva. Wilczynski i Warmbier (2000) dokazali su da krutost i čvrstoća spojeva raste s povećanjem dimenzija spoja, a utjecaj debljine čepa na koeficijent krutosti spoja linearan je. U radu Prekrat i sur. (2004) dokazano je da je inoviranim sastavom promijenjene geometrije i manjom površinom lijepljenja moguće postići jednake ili čak bolje rezultate koji se odnose na čvrstoću. Sparkes je (1974) proučavao utjecaj dubine natisnutosti i dimenzije moždanika te njihov međusobni razmak na čvrstoću spoja, dok su Kamenicky i Paulenkova (1984) kreirali formulu za procjenu ukupne čvrstoće lijepljenog spoja, u koju su uvrstili utjecaj dimenzije sljubnica. Osim navedenoga, ne treba zanemariti ni utjecaj oblika lijepljene površine na čvrstoću spoja, koju opisuju Prekrat i Smardzewski (2010).

Izbor ljepila ovisi o materijalu, zahtjevu čvrstoće i izdržljivosti zalijepljenog spoja, svrsi i uvjetima upotrebe proizvoda te o tehnologiji i načinu lijepljenja. Za lijepljenje spojeva u proizvodnji prozora uglavnom se rabe polivinilacetatna (PVAc) i poliuretanska (PUR) ljepila.

Polimerizacijska PVAc ljepila za drvo sastoje od polivinil-acetata i aditiva koji modificiraju ljepilo za određenu upotrebu. Osnovno je vezivo PVAc ljepila vodena disperzija polivinilacetata, koji se stvara pri polimerizaciji vinilacetata. Vinilacetat se može polimerizirati uz pomoć polimerizacije u masi, polimerizacijom otopine i emulzijskom polimerizacijom. U proizvodnji ljepila za drvo najčešće se upotrebljava emulzija sa sadržajem suhe tvari od 40 do 60 \% (Šernek i Kutnar, 2008).

Poliuretanska (PUR) ljepila nastaju poliadicijom izocianatnih polimera i poliola (alkohola s više $\mathrm{OH}$ skupina). Poznata su jednokomponentna, dvokomponentna, termo stabilna te taljiva ljepila. U drvnoj se industriji najčešće upotrebljavaju jednokomponentna PUR ljepila, i to za zahtjevna montažna lijepljenja, lijepljenje konstrukcijskih kompozita kao što su npr. nosači. Služe i za spajanje međusobno različitih materijala kao što su metali, guma i keramika. Pri primjeni jednokomponentnih ljepila preporučuje se da sadržaj vode u drvu bude veći od 8 \% (Resnik, 1997).
Tipični kutni spojevi koji se primjenjuju pri izradi prozora jesu spojevi s čepom, a rjeđe se rabe spojevi s moždanicima, s eliptičnim umecima i s klinastim zupcima. Među alternativna rješenja može se svrstati Hoffmannov spoj, u kojemu je presjek spojnog elementa u obliku dvostrukoga lastina repa (Hoffmann-Schwalbe, 2008).

Spoj s drvenim prstenom bio je patentiran u WIPO (World Intellectual Property Organisation) pod nazivom angular juncture for wooden frame constructions (PTC/SI2005/000030), dobio je zlatnu medalju na Međunarodnom sajmu inovacija (Salon International des Inventions) u Ženevi te na Međunarodnom sajmu inovacija u Nürnbergu (International Fachmesse »Ideen - Erfindungen - Neuheiten «). Navedeni se spoj sastoji od dviju okvirnica koje su međusobno sastavljene drvenim prstenom i vijkom, pri čemu vijak preuzima ulogu stezanja dviju okvirnica. Nakon otvrdnjavanja ljepila vijak se može ukloniti.

Cilj ovog istraživanja bio je utvrditi utjecaj vrste ljepila na silu loma kutnog spoja te odabrati najprikladnije ljepilo za proizvodnju prozorskih okvira i krila. Osim primjene različitih vrsta ljepila, ostali uvjeti ispitivanja u eksperimentu su bili jednaki za sve uzorke, a to se odnosi na površinu, krak djelovanja sile uvjetovane dimenzijama elemenata, postupak ispitivanja, obrada uzoraka te vlažnost drva. Usporedbom sila loma dobiven je pokazatelj izdržljivosti spojeva. Hipoteza istraživanja bila je da će se zbog bolje penetracije primijenjenog ljepila male viskoznosti postići veća čvrstoća spoja.

\section{MATERIJALI I METODE 2 MATERIAL AND METHODS}

Istraživanje se provodilo na novorazvijenom kutnom spoju s drvenim prstenom, uz upotrebu različitih ljepila (sl. 1). Elementi uzoraka bili su identičnoga poprečnog presjeka (sl. 2). Svi su elementi spojeni kosim sučeljem čelnih rubova pod kutom $45^{\circ}$. Za svaku skupinu ljepila izrađeno je šest uzoraka. Svi su uzorci izrađeni od radijalno ili radijalno-tangentne smrekovine homogene teksture, bez kvrga, smolnih vrećica i pukotina.

Za lijepljenje je upotrijebljeno PVAc ljepilo s otvrdnjivačem, dva dvakomponentna epoksi ljepila, dva PVAc ljepila u klasi D3, dva PUR ljepila i PUR ljepilo sa staklenim vlaknima. Uzorci su bili kondicionirani u laboratorijskom prostoru. Testiranje je provedeno sedam dana nakon lijepljenja. Temperatura u vrijeme testiranjem bila je $18{ }^{\circ} \mathrm{C}$, a relativna vlaga $44 \%$. Sadržaj vode u elementima u procesu lijepljenja bio je $12 \%$. Ovisno o vrsti ljepila, grupe ispitnih uzoraka bile su označene slovima A, B, C, D, E, F, G i H.

Sila loma kutnih prozorskih profila slijepljenih različitim ljepilima testirana je kidalici u laboratoriju tvrtke Jelovica d.d. (sl. 3). Za utvrđivanje čvrstoće i trajnosti slijepljenog drva primjenjuju se različite metode i postupci (Mihulja i Bogner, 2005). Standardna (JUS D.E8.008, 1987) metoda ispitivanja prilagođena 
... Horvatin, Zupančić, Šernek, Oblak: Usporedba momenta loma kutnog spoja izvedenoga...

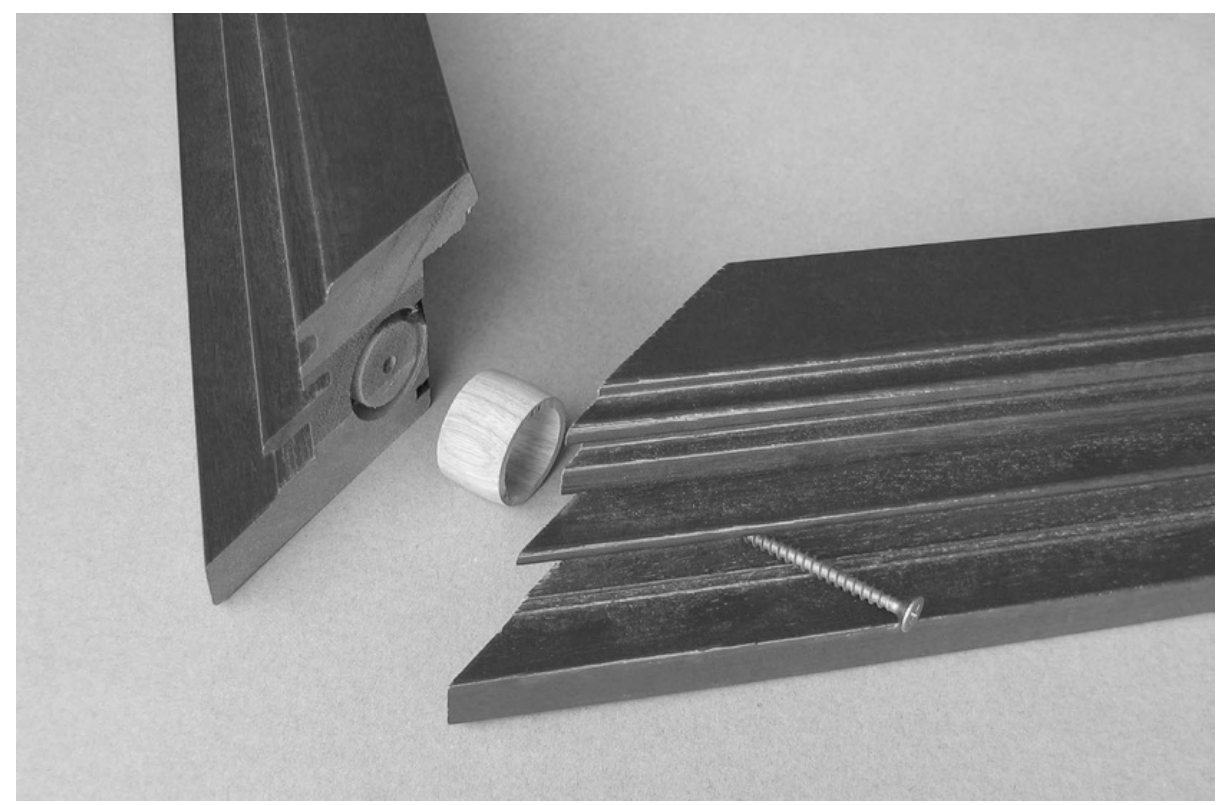

Slika 1. Kutni spoj s drvenim prstenom

Figure 1 Corner joint with a wooden ring

je prethodnim istraživanjem drugih autora - Korzeniowskog (1982), Warmbiera i Wilczynskog (2000). Uzorci su bili pripremljeni kao što je prikazano na slici 4. Dužina krakova uzoraka bila je $450 \mathrm{~mm}$. Za učvršćenje uzoraka u kidalicu na krajevima krakova izbušene su rupe promjera $8,5 \mathrm{~mm}$. Vlačna je sila u kidalici postupno povećavana do loma. Vrijednosti sile do trenutka loma mjerene su i kontinuirano bilježene u njutnima $(\mathrm{N})$.
Sila loma kao kriterij definiranja kvalitete spoja odredio je proizvođač. Budući da su svi uzorci bili istovrsni, nije bilo potrebno izračunavati čvrstoću. U slučaju potrebe usporedbe rezultata $\mathrm{s}$ rezultatima drugih vrsta spojeva, uz pomoć opisa i dimenzija izrađenih elemenata spoja bilo je lako izračunati čvrstoću.
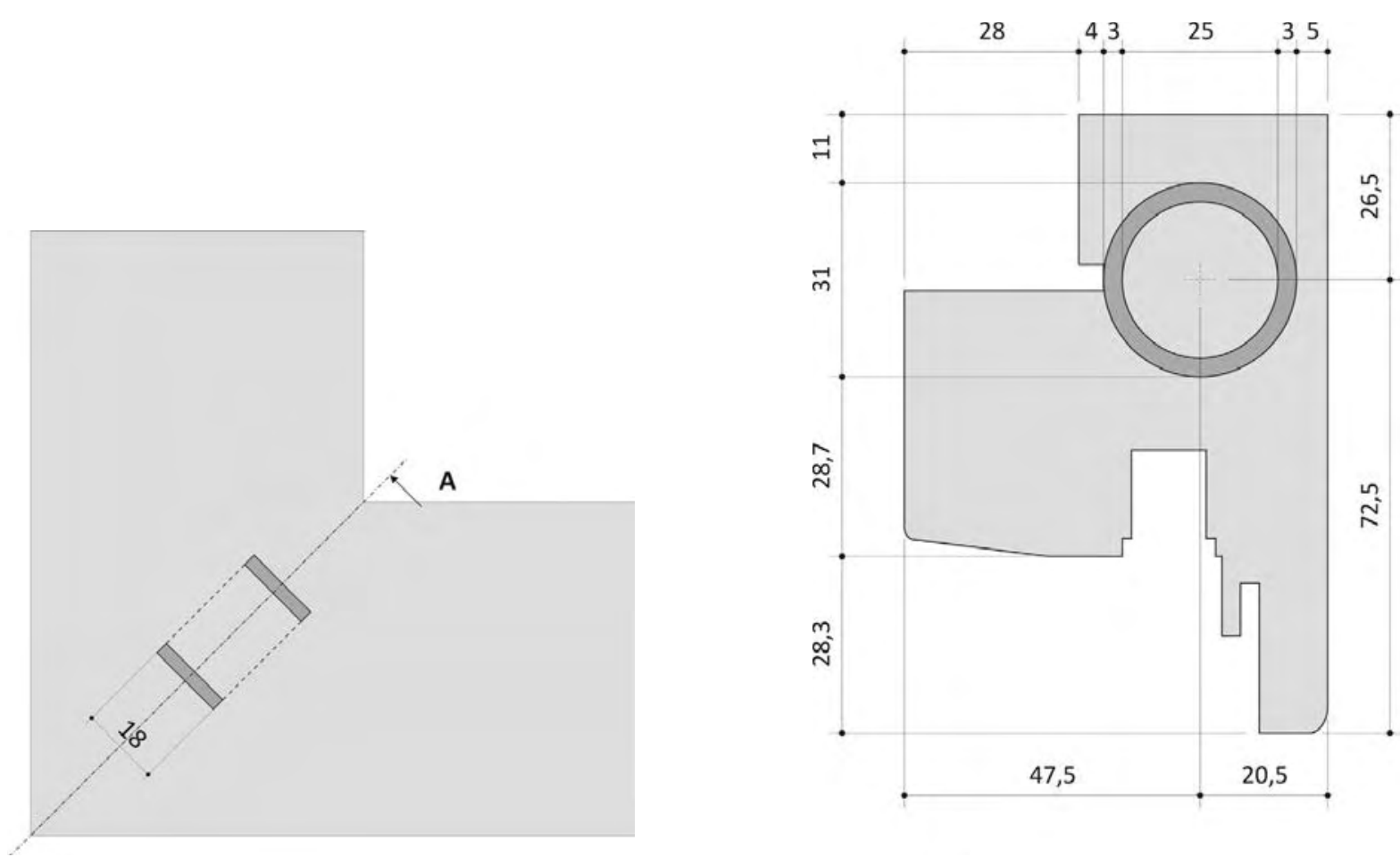

Slika 2. Dimenzije kutnog spoja s drvenim prstenom na izabranome prozorskom profilu Figure 2 Dimensions of a corner joint with wooden ring and with chosen window profile 


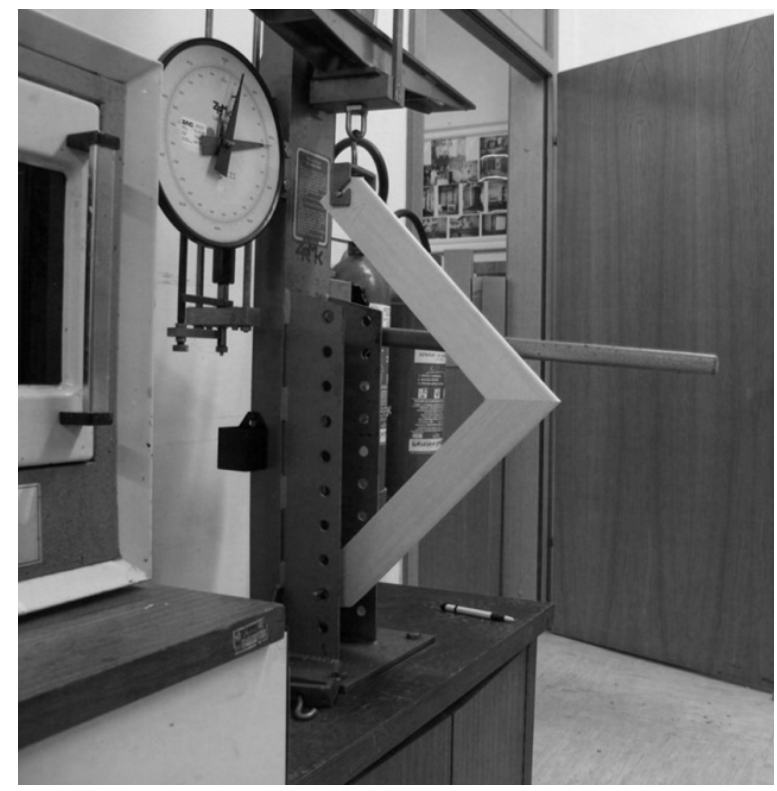

Slika 3. Uzorak u kidalici

Figure 3 Sample gripped into the tensile-testing machine

\section{REZULTATI ISTRAŽIVANJA \\ 3 RESULTS AND DISCUSSION}

Tablica 1. prikazuje vrijednosti sile loma uzoraka ispitanih u kidalici za svih šest uzoraka iz svake skupine.

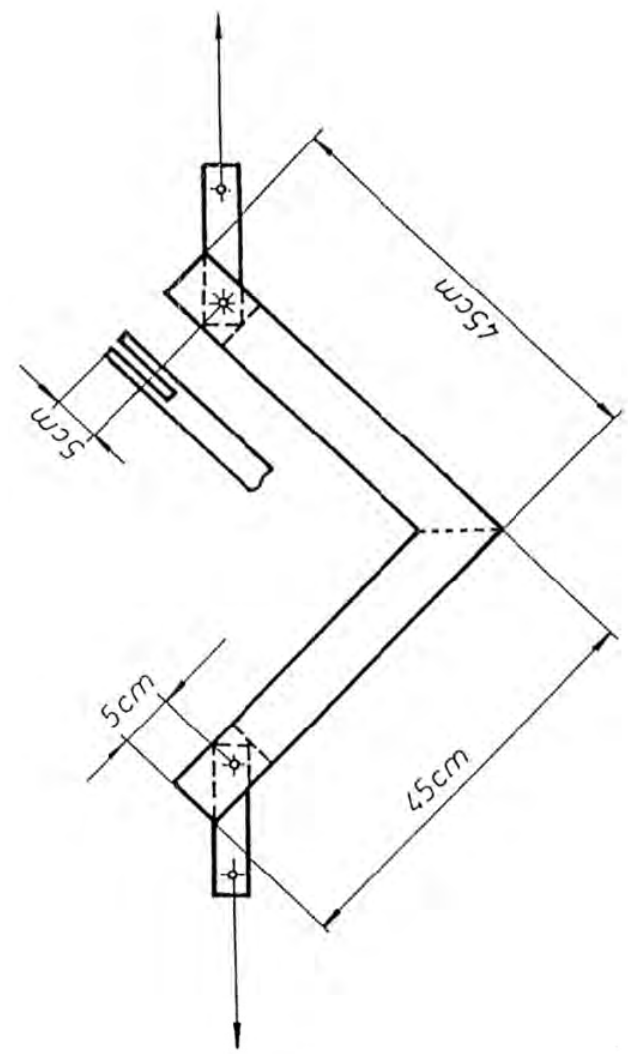

Slika 4. Skica s dimenzijama uzoraka

Figure 4 Sample dimensions

Tablica 1. Sile loma u njutnima (N) i izračunani momenti loma $(\mathrm{Nm})$

Table 1 Fracture forces in Newtons $(\mathrm{N})$ and moment of fracture (Nm)

\begin{tabular}{|c|c|c|c|c|c|c|c|c|c|c|c|}
\hline \multirow{3}{*}{\multicolumn{2}{|c|}{$\begin{array}{l}\text { Skupina - vrsta lijepila } \\
\text { Group - type of adhesive }\end{array}$}} & \multirow{3}{*}{$\begin{array}{c}\text { Viskoznost } \\
\text { - ISO 2555 } \\
\text { (mPa.s) } \\
\text { Viscosity } \\
\text { - ISO 2555 } \\
\text { (mPa.s) }\end{array}$} & \multicolumn{6}{|c|}{$\begin{array}{c}\text { Uzorci } \\
\text { Test items }\end{array}$} & \multirow{3}{*}{$\begin{array}{c}\begin{array}{c}\text { Prosječna } \\
\text { vrijednost: } \\
\text { sile loma }(\mathbf{N})\end{array} \\
\text { momenta } \\
(\mathbf{N m}) \\
\text { Average } \\
\text { value } \\
\text { fracture force } \\
\frac{(N)}{\text { moment }(\mathrm{Nm})}\end{array}$} & \multirow{3}{*}{\multicolumn{2}{|c|}{ 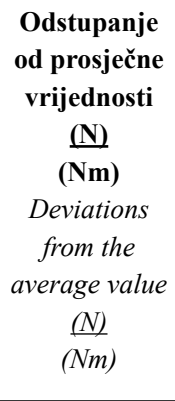 }} \\
\hline & & & 1 & 2 & 3 & 4 & 5 & 6 & & & \\
\hline & & & \multicolumn{6}{|c|}{$\begin{array}{c}\text { Vrijednost: } \\
\text { sile loma }(\mathrm{N}) \\
\text { momenta }(\mathrm{Nm}) \\
\text { Value of: } \\
\text { fracture force }(\mathrm{N}) \\
\text { moment }(\mathrm{Nm})\end{array}$} & & & \\
\hline \multirow{2}{*}{ A } & PVA s otvrdnjivačem & \multirow{2}{*}{$\sim 12000$} & $\underline{860}$ & $\underline{940}$ & $\underline{980}$ & $\underline{950}$ & $\underline{890}$ & $\underline{940}$ & $\underline{927}$ & +53 & \\
\hline & PVA with hardener & & 308 & 338 & 353 & 342 & 320 & 338 & 334 & +19 & \\
\hline \multirow{2}{*}{ B } & dvokomponentno epoksi lijepilo 1 & \multirow{2}{*}{$\sim 65000$} & $\underline{760}$ & $\underline{760}$ & $\underline{800}$ & $\underline{790}$ & $\underline{750}$ & $\underline{780}$ & $\underline{773}$ & +27 & -23 \\
\hline & two-component epoxy adhesive 1 & & 274 & 274 & 288 & 284 & 270 & 281 & 278 & +10 & -8 \\
\hline \multirow{2}{*}{ C } & PVA ljepilo 1, klase D3 & \multirow{2}{*}{$\sim 13000$} & $\underline{1480}$ & $\underline{1160}$ & $\underline{1400}$ & $\underline{1390}$ & $\underline{1210}$ & $\underline{1440}$ & $\underline{1347}$ & $+\underline{133}$ & -187 \\
\hline & PVA 1, class D3 & & 533 & 418 & 504 & 500 & 436 & 518 & 485 & +48 & -67 \\
\hline \multirow{2}{*}{$\mathrm{D}$} & dvokomponentno epoksi lepilo 2 & & $\underline{980}$ & $\underline{1110}$ & $\underline{1350}$ & $\underline{1190}$ & $\underline{1270}$ & $\underline{1140}$ & $\underline{1173}$ & +177 & -193 \\
\hline & two-component epoxy adhesive 2 & & 353 & 400 & 486 & 428 & 457 & 410 & 422 & +64 & -69 \\
\hline \multirow{2}{*}{$\mathrm{E}$} & PVA ljepilo 2, klase D3 & \multirow{2}{*}{$\sim 13500$} & $\underline{1100}$ & $\underline{1120}$ & $\underline{900}$ & $\underline{990}$ & $\underline{1040}$ & $\underline{1090}$ & $\underline{1040}$ & +80 & -140 \\
\hline & PVA 2, class D3 & & 396 & 403 & 324 & 356 & 374 & 392 & 374 & +29 & -50 \\
\hline \multirow{2}{*}{$\mathrm{F}$} & PUR ljepilo sa staklenim vlaknima & \multirow{2}{*}{$\sim 10500$} & $\underline{1140}$ & $\underline{1060}$ & $\underline{990}$ & $\underline{1100}$ & $\underline{1080}$ & $\underline{1010}$ & $\underline{1063}$ & +77 & -73 \\
\hline & $P U R+$ glass fiber & & 410 & 382 & 356 & 396 & 389 & 364 & 383 & +27 & -27 \\
\hline \multirow{2}{*}{ G } & PUR ljepilo 1 - jednokomponentno & \multirow{2}{*}{$\sim 8000$} & $\underline{800}$ & $\underline{800}$ & $\underline{870}$ & $\underline{790}$ & $\underline{830}$ & $\underline{850}$ & $\underline{823}$ & +74 & -33 \\
\hline & PUR 1, one - component & & 288 & 288 & 313 & 284 & 299 & 306 & 296 & +17 & -12 \\
\hline \multirow[b]{2}{*}{$\mathrm{H}$} & PUR ljepilo 2 - jednokomponentno & & $\underline{1150}$ & $\underline{1200}$ & $\underline{1180}$ & $\underline{1170}$ & $\underline{1190}$ & $\underline{1170}$ & 1177 & +23 & -27 \\
\hline & PUR 2, one - component & & 414 & 432 & 425 & 421 & 428 & 421 & 424 & +8 & -10 \\
\hline
\end{tabular}


Na slici 5. prikazana je usporedba prosječnih vrijednosti sile loma po pojedinim skupinama. Bijelom bojom obilježena je prosječna vrijednost u skupini A, koja je izabrana kao referentna skupina. U predistraživanju je utvrđeno da je spoj s drvenim prstenom zalijepljen PVAc ljepilom s otvrdnjivačem dao zadovolja- vajuću čvrstoću za prozorske okvire u masovnoj proizvodnji. Tamnosivom bojom označene su skupine koje su dale bolje rezultate u usporedbi s referentnom skupinom A. Svijetlosivom su bojom označene skupine čiji su rezultati lošiji od onih u skupini A.

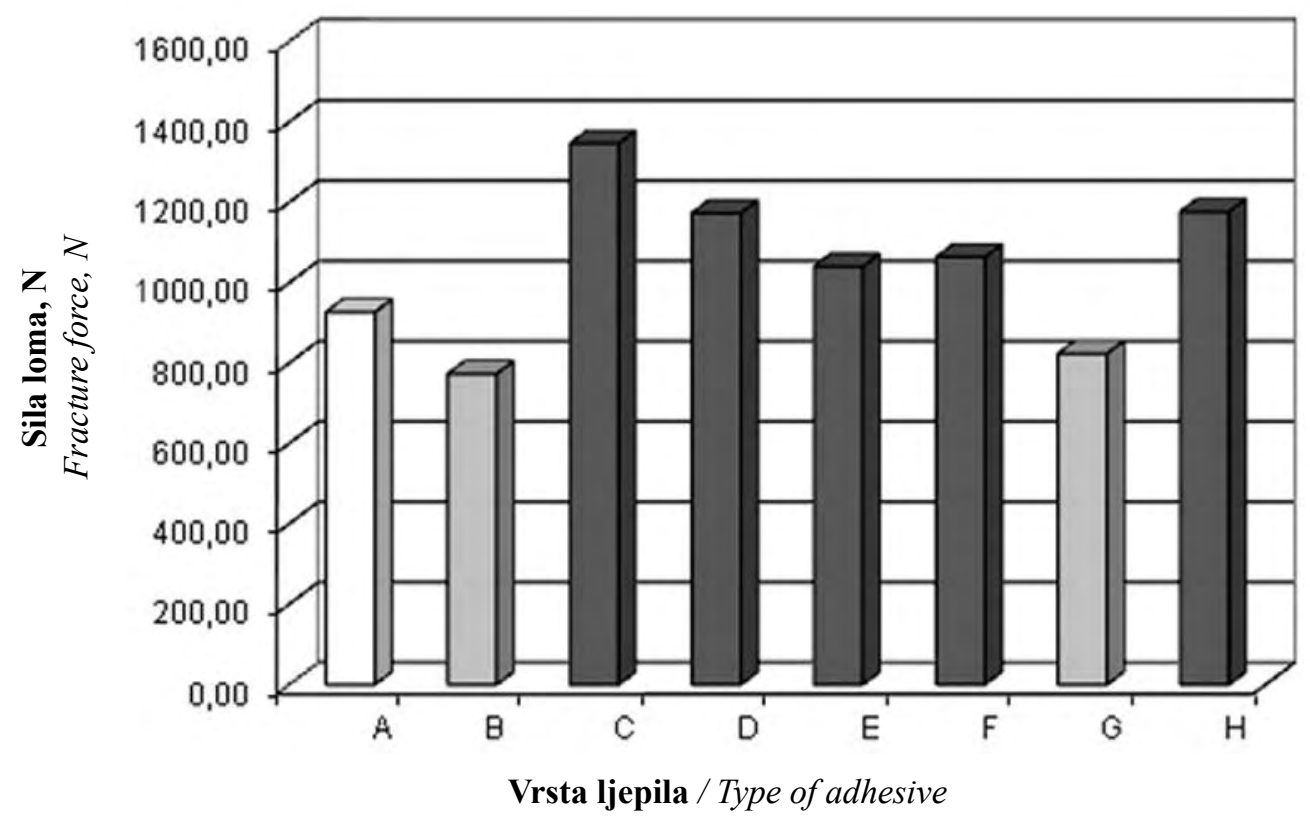

Slika 5. Usporedba prosječne sile loma s obzirom na vrstu ljepila

Figure 5 Comparison of destructive forces depending on type of adhesive

Rezultati ispitivanja pokazali su da viskoznija ljepila daju lošije rezultate. Primjer je dvokomponentno epoksi ljepilo za opću uporabu, koje je upotrijebljeno u ispitivanju (skupina B). Manja sila loma od referentne uočena je i za poliuretansko ljepilo (skupina G), koje se pri otvrdnjavanju pjeni. Može se pretpostaviti da ljepilo skupine B zbog velike viskoznosti vjerojatno preslabo prodire u drvo. U kutnom spoju s drvenim prstenom postoji gotovo tupi sljub čelnog presjeka, pri čemu je odgovarajuća penetracija ljepila izuzetno važna za čvrstoću spoja. Pjenjenje ljepila pri otvrdnjavanju također smanjuje silu loma, pri čemu su važne veličina i količina mjehurića koji se pojavljuju u procesu otvrdnjavanja. Mjehurići su se pojavljivali i u uzorcima skupine F, no veće vrijednosti sile loma od referentne mogu se objasniti manjim brojem i manjim dimenzijama mjehurića. Najbolji su rezultati postignuti ljepilom skupine C (PVA ljepilo klase D3).

Spoj s drvenim prstenom omogućuje proizvodnju prozorskih okvira od potpuno mehanički i površinski obrađenih elemenata, što ga razlikuje od uobičajene proizvodnje prozora utorima i perima te čepovima.

Iako je proizvodnja od gotovo sasvim obrađenih elemenata navedena kao jedna od prednosti, taj način proizvodnje ima i potencijalne nedostatke. Pritom se osobito misli na to da možda ljepilo zbog nedostataka preciznosti nije naneseno preko cijele površine sljubnice. Zbog toga je u eksperiment uključeno i poliuretansko ljepilo koje tijekom otvrdnjavanja ekspandira. Treba naglasiti da poliuretanska ljepila, koja se pri otvrdnjavanju jako pjene, nisu prikladna, što dokazuju i rezultati ispitivanja.

Jedina alternativa spoju s drvenim prstenom koja je pronađena u literaturi jest Hoffmannov spoj sa spojnim elementom u obliku dvostrukoga lastina repa, koji se u praksi već potvrdio. No njegov je nedostatak vidljivosti spojnog elementa s jedne strane te se može koristiti samo na prozorima na kojima je dio s vidljivim spojnim elementom prekriven zaštitnim aluminijskim slojem. Hoffmannovim spojem moguće je također proizvesti i prozorski okvir s unaprijed obrađenim profiliranim i površinski obrađenim elementima. Problem zaštite spoja od prodora vlage jednak je, dakle, kao i pri spoju s drvenim prstenom. Ljepila u skupini C, D, E, F i $H$ pokazala su se primjerenima s mehaničko-tehničkog gledišta, no ostaje problem trajnosti kad su okviri prozora izrađeni od prethodno obrađenih elemenata.

\section{ZAKLJUČAK \\ 4 CONCLUSION}

Najbolje rezultate dao je spoj lijepljen PVAc ljepilom klase D3 (skupina C). Lošiji rezultati u referentnih dobiveni su pri upotrebi viskoznijih lijepila koja slabije prodiru u drvo.

Pri odabiru optimalnog ljepila za kutne spojeve prozorskih okvira nije važna samo sila loma spoja, koja ovisi o upotrijebljenom ljepilu, već i svojstvo zapunjavanja nezaštićenoga poprečnog presjeka eleme- 
nata od drva. To je osobito važno za proizvodnju prozorskih okvira iz unaprijed strojno i površinski obrađenih elemenata. Uporabljena ljepila manjeg viskoziteta i ona (uglavnom poliuretanska ljepila) koja se tijekom otvrdnjavanja pretjerano ne pjene, pogodnija su za izradu prozorskih okvira kutnim spojem s drvenim prstenom.

\section{LITERATURA}

\section{REFERENCES}

1. Dziegelewski, S.; Zenkteler, M., 1975: Badania nad polaczeniami szkieletowych konstrukciji mebla z drewna, Folia Forestalia Polonica, seria B, 12: 133-156.

2. Govže, A., 2005: Angular juncture for wooden frame constructions, International Patent. No.: PCT/ SI2005/000030.

3. Hill, M. D.; Eckelman, C. A., 1973: Flexibility and bending strength of mortise and tanon joints, Furniture Design and Manufacturing, 45 (1/2): 54-61.

4. Kamenicky, J.; Paulenkova, M., 1984: Rovnice na vypočet unosnosti kolikovych nabytkovych spojov zo smrekoveho drevo. Drevarsky Vyskum, 29 (2): 53-67.

5. Korzeniowski, A., 1982: Fit improves properties of joints, Furniture manufacturer, 47 (558): 45 - 46.

6. Marra, A.M., 1992: Technology of wood bonding : principles and practice, New York: Van Nostrand Reinhold, 454.

7. Mihulja, G.; Bogner, A., 2005: Strength and durability of glued wood. Part one: Factors of glued joint strength. Drvna industrija, 56 (4): 69-78.

8. Nussbaum, R. M.; Sterley, M., 2002: The effect of wood extractive content on glue adhesion and surface wettability of wood, Wood and Fiber Science, 34 (1): 57-71.

9. Jazbec, A.; Prekrat, S., 2004: Analysis of the bending moment of innovative corner joints during static testing, Wood research, 49 (1): 32-32
10. Prekrat, S.; Smardzewski, J., 2010: Effect of Glueline Shape on Strength of Mortise and Tenon Joint. Drvna industrija, 61 (4): 223-228.

11. Resnik, J., 1997: Lepila in lepljenje lesa : (okvirna skripta). 1. ponatis. Ljubljana: Biotehniška fakulteta, Oddelek za lesarstvo, 103.

12. Singh, A. P.; Anderson, C. R.; Warnes, J. M.; Matsumura, J., 2002: The effect of planing on the microscopic structure of Pinus radiata wood cells in relation to penetration of PVA glue. Holz als Roh- und Werkstoff, 60: 333-341.

13. Sparkes, A. J., 1974: The strength of mortise and tenon joints. Furniture Industry Res. Assoc. Great Britain: Maxwell Road Stevenage Hertfordshire.

14. Šernek, M., Kutnar, A., 2008: Polivinilacetatna lepila za les = Polyvinyl acetate adhesives for wood. Les, 60 (10): 364-370.

15. Tankut, N., 2007: The effect of adhesive type and bond line thickness on the strength of mortise and tenon joints. International Journal of Adhesion and Adhesives, 27 (6): 493-498.

16. Warmbier, K.; Wilczynski, A., 2000: Strength and stiffness of dowel corner joints - effect of joint dimensions, Folia Forestalia Polonica, seria B, 31: 29-41.

17. Wilczynski, A.; Warmbier, K., 2003: Efect of joint dimensions on strength of stiffness of tenon joints, Folia Forestalia Polonica, seria B, 34: 53-66.

18. ***JUS D.E8.008, 1987: Građevinska stolarija - ispitivanje lepljenih veza elemenata krila prozora i balkonskih vrata, 3.

19. *** 2008: Hoffmann-Schwalbe, http://www.hoffmannschwalbe.de/Frames.php?lang=en (pristupljeno: 15. srpnja 2008).

\section{Corresponding address:}

Associate Professor JASNA HROVATIN, Ph.D.

Faculty of Design

Prevale 10

1236 Trzin, SLOVENIA

e-mail: jasna.hrovatin@fd.si 